\title{
Bacterial Diversity in the Digestive Tracts of Four Indian Air-Breathing Fish Species Investigated by PCR Based Denaturing Gradient Gel Electrophoresis
}

\author{
Suxu He ${ }^{1}$, Zhigang Zhou' ${ }^{1}$ Goutam Banerjee², Lu Huang', Arun Kumar Ray ${ }^{2}$, Einar \\ Ring $\varnothing^{3}$. \\ ${ }^{1}$ Key Laboratory for Feed Biotechnology of the Ministry of Agriculture, Feed Research Institute, Chinese Academy \\ of Agricultural Sciences, Beijing, China; ${ }^{2}$ Visva-Bharati University - Zoology, Santiniketan, India; ${ }^{3}$ The Arctic \\ University of Norway, Troms $\phi$, Norway
}

\begin{abstract}
An investigation was conducted to identify the allochthonous microbiota (entire intestine) and the autochthonous microbiota in proximal intestine (PI) and distal intestine (DI) of four species of Indian air-breathing fish (climbing perch; Anabas testudineus, murrel; Channa punctatus, walking catfish; Clarias batrachus and stinging catfish; Heteropneustes fossilis) by PCR based denaturing gradient gel electrophoresis (DGGE). High similarities of the allochthonous microbiota were observed between climbing perch and murrel, walking catfish and stinging catfish, indicating similar food behavior. The autochthonous microbiota of PI and DI from climbing perch and murrel revealed more similarity, than the result obtained from walking catfish and stinging catfish. The autochthonous microbiota of climbing perch and murrel were similar with regard to the allochthonous microbiota, but no such similarity was observed in case of walking catfish and stinging catfish. The fish genotype and intestinal bacteria are well matched and show co-evolutionary relationship. Three fish species has its unique bacteria; autochthonous Enterobacter cloacae, Edwardsiella tarda and Sphingobium sp. in DI of climbing perch, Pseudomonas sp.; allochthonous and autochthonous in PI of walking catfish and uncultured bacterium (EU697160.1), uncultured bacterium (JF018065.1) and uncultured bacterium (EU697160.1) for stinging catfish. In murrel, no unique bacteria were detected.
\end{abstract}

Key words: Allochthonous and autochthonous gut microbiota, air-breathing fish, bacterial diversity, DGGE

\footnotetext{
*Author for correspondence: aray51@yahoo.com
} 


\section{INTRODUCTION}

The gastrointestinal (GI) tract of an animal consists of a very complex and dynamic microbial ecosystem which is very important from a nutritional, physiological and pathological point of view ${ }^{1-3}$. Being rich in nutrients, the digestive tract of fish, in comparison with the surrounding water, confers a favorable growth environment for microorganisms ${ }^{4,5}$. It is generally accepted that the GI tract microbiota of fish are defined as either autochthonous (indigenous) bacteria, able to colonize the epithelial surface of the host, or allochthonous (transient) bacteria ${ }^{6}$. In several studies, the culturable gut bacterial communities of various Indian craps have been reported ${ }^{7-12}$. The fish gut bacterial communities may contain pathogenic, symbiotic and commensal bacteria and they can exert great effect on the host welfare which may result in mucosal tolerance or inflammation 13,14. Elucidation of the gut microbiota, both allochthonous and autochthonous of four Indian air-breathing fish species is an essential step in developing strategies and dietary applications to fortify and modulate these communities.

Historically, the general approach to study the gut microbiota of fish was by use of conventional culture methods ${ }^{4,15}$. However, conventional culture methods are often time consuming and lack accuracy and sensitivity in characterizing certain fastidious and obligate anaerobes that require special culture and growth conditions 16-20. Therefore, culture based studies of the GI microbiota leads to an uncertain picture of the microbial community residing in the GI tract. Nowadays, several novel molecular technologies, such as genetic fingerprint method based on polymerase chain reaction (PCR) amplification of 16S rDNA and denaturing gradient gel electrophoresis (DGGE) have become a popular method to investigate the gut microbiota in fish ${ }^{17-}$ $19,21,22$. However, it's still limitation in the efficiency of DNA extraction and the PCR amplification process affecting the DGGE bands, and that the concentration of the microbial species detection limits ranging between $10^{4}$ and $10^{8} \mathrm{CFU}$ $\mathrm{mL}^{-1}$ 23. Although some information on the identification of autochthonous bacteria in the GI tract of Indian freshwater fish are available ${ }^{2,24,25}$. To our knowledge no information is available on the use of culture-independent methods to evaluate the gut microbiota of Indian freshwater fish. The aim of the present study was therefore to investigate the allochthonous; from the entire intestine and the autochthonous gut microbiota from proximal and distal intestine of four species of adult Indian air-breathing fish (climbing perch, murrel, walking catfish and stinging catfish) using the PCR-DGGE approach.

\section{MATERIALS AND METHODS}

\section{Experimental fish and their maintenance}

Four species of adult Indian air-breathing fish, the climbing perch (Anabas testudineus), murrel (Channa punctatus), walking catfish (Clarias batrachus) and stinging catfish (Heteropneustes fossilis) were used in the present study (Table 1). The fish were obtained from a local fish farm near Santiniketan, West Bengal, India $\left(23^{\circ} 41^{\prime} 30^{\prime \prime} \mathrm{N}\right.$ latitude and $87^{\circ} 41^{\prime \prime} 20^{\prime \prime}$ E longitude). Six individuals of each fish species were randomly selected and killed with sharp blow on the head. The ventral surface of the fish were carefully scrubbed with $1 \%$ iodine solution to remove unwanted material. The fish were dissected on ice and the entire intestinal tract was aseptically removed quickly inside the laminar air flow ${ }^{26}$. Intestinal contents from the entire intestine containing non-adherent (allochthonous) bacteria were immediately transferred to sterile Nunc tubes containing $96 \%$ ethanol according to Liu et al. ${ }^{21}$. For detection of the autochthonous gut microbiota, the digestive tracts were divided into proximal intestine (PI) and distal intestine (DI) according to He et al. ${ }^{27}$. Each sample, pooled from six fish were homogenized separately using automatic homogenizer (Omni homogenizer) and the samples were transferred to $1.5 \mathrm{~mL}$ Eppendorf tubes and stored at $-20^{\circ} \mathrm{C}$ until further use. Analysis of pooled samples from several individuals is a normal procedure for evaluating the gut microbiota by PCR-DGGE ${ }^{28-30}$ to avoid individual variations in the gut microbiota ${ }^{30-32}$. 
Table 1- Food habits, average live weight, average fish length, relative intestinal length and average intestine weight of the air-breathing fish species examined.

\begin{tabular}{|c|c|c|c|c|}
\hline Fish species & Feeding habit ${ }^{*}$ & $\begin{array}{l}\text { Average live } \\
\text { weight }(\mathrm{g}) \\
(\mathrm{SD})^{1}\end{array}$ & $\begin{array}{l}\text { Relative } \\
\text { intestinal } \\
\text { length }^{2}\end{array}$ & $\begin{array}{l}\text { Average intestinal } \\
\text { weight }(\mathrm{g})(\mathrm{SD})^{1}\end{array}$ \\
\hline Anabas testudineus & $\begin{array}{l}\text { Insects, insect larvae, } \\
\text { water fleas, smaller fish, } \\
\text { vegetable debris etc. }\end{array}$ & $65.2(2.9)$ & 0.43 & $7.2(0.61)$ \\
\hline Channa punctatus & $\begin{array}{l}\text { Insects, zooplankton, } \\
\text { insect larvae, small fish }\end{array}$ & $86.1(2.4)$ & 0.51 & $2.89(0.51)$ \\
\hline Clarias batrachus & $\begin{array}{l}\text { Insect larvae, shrimps, } \\
\text { worms }\end{array}$ & $94.1(3.2)$ & 0.50 & $9.2(0.58)$ \\
\hline Heteropneustes fossilis & $\begin{array}{l}\text { Insect larvae, shrimps, } \\
\text { worms, small fish, } \\
\text { organic debris }\end{array}$ & $70.8(4.2)$ & 0.53 & $3.11(0.61)$ \\
\hline
\end{tabular}

* Jhingran $(1997)^{59}$

${ }^{1}$ Standard deviation given between brackets, $\mathrm{n}=6$.

${ }^{2}$ Relative intestinal length $=$ length of intestine $(\mathrm{cm}) /$ total length of fish $(\mathrm{cm})$.

\section{DNA extraction}

DNA was extracted from homogenized gut samples (Table 2) from the four fish species according to $\mathrm{Yu}$ and Morrison ${ }^{33}$ with modification described by $\mathrm{He}$ et al. ${ }^{27}$. The quality of the extracted was checked on $0.8 \%$ agarose gels, stained with ethidium bromide, visualized on a UV transilluminator (Gel Doc 2000, BIORAD).

Table 2- Gut samples from four species of Indian air-breathing fish.

\begin{tabular}{ccc}
\hline Sample no. & Fish species & Part of the intestine evaluated \\
& & \\
1 & Anabas testudineus & Entire intestine (allochthonous microbiota) \\
2 & Anabas testudineus & Proximal intestine (autochthonous microbiota) \\
3 & Anabas testudineus & Distal intestine (autochthonous microbiota) \\
4 & Channa punctatus & Entire intestine (allochthonous microbiota) \\
5 & Channa punctatus & Proximal intestine (autochthonous microbiota) \\
6 & Channa punctatus & Distal intestine (autochthonous microbiota) \\
7 & Clarias batrachus & Entire intestine (allochthonous microbiota) \\
8 & Clarias batrachus & Proximal intestine (autochthonous microbiota) \\
9 & Clarias batrachus & Distal intestine (autochthonous microbiota) \\
10 & Heteropneustes fossilis & Entire intestine (allochthonous microbiota) \\
11 & Heteropneustes fossilis & Proximal intestine (autochthonous microbiota) \\
12 & Heteropneustes fossilis & Distal intestine (autochthonous microbiota) \\
\hline
\end{tabular}

\section{PCR -DGGE}

The V3 region of the $16 \mathrm{~S}$ rrs gene was amplified with primers 338-GC-f (5'CGCCCGCCGCGCGCGGCGGGCGGGGCGG GGGCACGGGGGGACTCCTACGGGAGGCA GCA-3') and 519r (5'ATTACCGCGGCTGCTGG-3'). The PCR reaction mixture ( $50 \mu \mathrm{L}$ total volume) contained 5 $\mu \mathrm{L}$ of $10 \times$ PCR Buffer, $4 \mu \mathrm{L}$ of $2.5 \mathrm{mM}$ deoxynucleotide triphosphate mixture, $2.5 \mu \mathrm{L}$ of $20 \mathrm{mg} \mathrm{mL}^{-1}$ bovine serum albumin, $1 \mu \mathrm{L}$ of each primer (at $10 \mu \mathrm{M}$ ), $1 \mu \mathrm{L}$ of $5 \mathrm{U}_{\mu \mathrm{L}^{-1}}$ Taq polymerase, and $2 \mu \mathrm{L}$ DNA template. The amplification condition was $94^{\circ} \mathrm{C}$ for $5 \mathrm{~min}$ (initial denaturation), followed by 30 cycles of denaturation at $94^{\circ} \mathrm{C}$ for $30 \mathrm{sec}$, annealing at $55^{\circ} \mathrm{C}$ 
for $30 \mathrm{sec}$, and extension at $72^{\circ} \mathrm{C}$ for $30 \mathrm{sec}$. A final extension step was carried out at $72^{\circ} \mathrm{C}$ for 5 min. The PCR products were confirmed by electrophoresis on $1.5 \%$ agrose gel.

PCR-DGGE was performed according to Liu et al. ${ }^{21}$ and Zhou et al. ${ }^{34}$ using a DCode universal Mutation System (Bio-Rad Laboratories, Hercules, CA). About $800 \mathrm{ng}$ PCR products were separated on $10 \%(\mathrm{wt} / \mathrm{vol})$ polyacrylamide gels (40\% acrylamide/bis solution, 37.5:1; Bio-Rad Laboratories, Hercules, CA) in $1 \times$ TAE $(40 \mathrm{mM}$ Tris, $20 \mathrm{mM}$ Acetate, $1.0 \mathrm{mM} \mathrm{Na} 2$-EDTA) using denaturing gradient ranges of 40 to $60 \%$ ureaformamide denaturing gradient. Electrophoresis was performed at $60 \mathrm{~V}, 60^{\circ} \mathrm{C}$ for $12 \mathrm{hr}$. Gels were then stained using ethidium bromide solution $(0.5$ $\mathrm{mg} \mathrm{mL}{ }^{-1}$ in Tris-acetate-EDTA buffer for $20 \mathrm{~min}$ ), visualized on a UV transilluminator, and photographed. The appropriate bands were excised, re-amplified, and purified (TIAN quick Midi purification Kit, Tiangen, China), then sequenced.

\section{Sequence and data analysis}

Selected DGGE bands were excised from the gel with a sterile scalpel blade and incubated overnight at $4^{\circ} \mathrm{C}$ with $50 \mu \mathrm{L}$ of $0.5 \times \mathrm{TE}$ buffer to allow diffusion of the DNA. The PCR amplification was performed as described earlier with the same primers, adding $2 \mu \mathrm{L}$ of the solution of extracted DNA. The purified product were cloned to pEasy- $\mathrm{T}$ vector (Transgen, Beijing, China), and the right clone were sent to Sanbo Biotech (Beijing, China) for sequence.
Based on the presence or absence of bands a matrix character was elaborated, from which NeiLi/Dice's coefficient of similarity was calculated and used to construct an UPGMA (Unweighted Pair Group Method with Arithmetic Mean).

\section{RESULTS}

\section{DGGE profile}

The 16S rDNA V3 region fingerprints of the allochthonous and autochthonous gut microbiota of four species of Indian air-breathing fish are shown in Figure 1, and eighteen distinct bands were revealed in the DGGE gels. The band distribution of 16S rDNA V3 fragments from the different fish species, varied from 2 bands; autochthonous bacteria in PI of climbing perch to 11 bands; allochthonous bacteria of stinging catfish. The similarity coefficients (Cs) of the band patterns are displayed in Figure 2 and Table 3. The intestinal microbiota derived from these four fish species could be divided into four groups based on the cluster analysis results (Fig. 2), cluster 1, 1(entire intestine for climbing perch), 4 (entire intestine for murrel) and 3 (DI for climbing perch); cluster 2, 2 (PI for climbing perch), 5 (PI for murrel), 6 (DI for murrel) and 8 (PI for walking catfish); cluster 3, 9 (DI for walking catfish), 11 (PI for stinging catfish) and 12 (DI for stinging catfish); cluster 4, 7 (entire intestine for walking catfish) and 10 (entire intestine for stinging catfish).

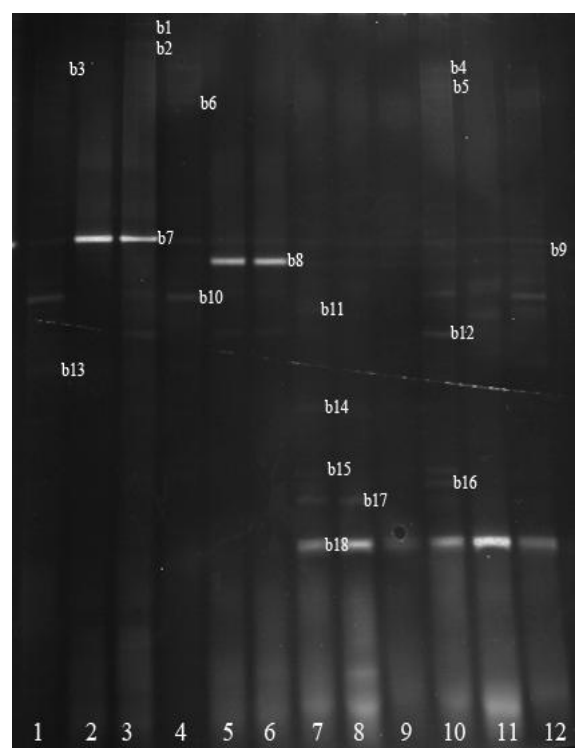

Figure 1- Denaturing gradient gel electrophoresis fingerprints of the 16S rDNA V3 region of the adhesive gut 
bacterial communities from four species of Indian air-breathing fish.1,2,3:climbing perch (Anabas testudineus);4,5,6: murrel (Channa punctatus);7,8,9: walking catfish (Clarias batrachus) and 10,11,12: stinging catfish(Heteropneustes fossilis). Total 18 bands have been detected and identified by sequencing analysis.

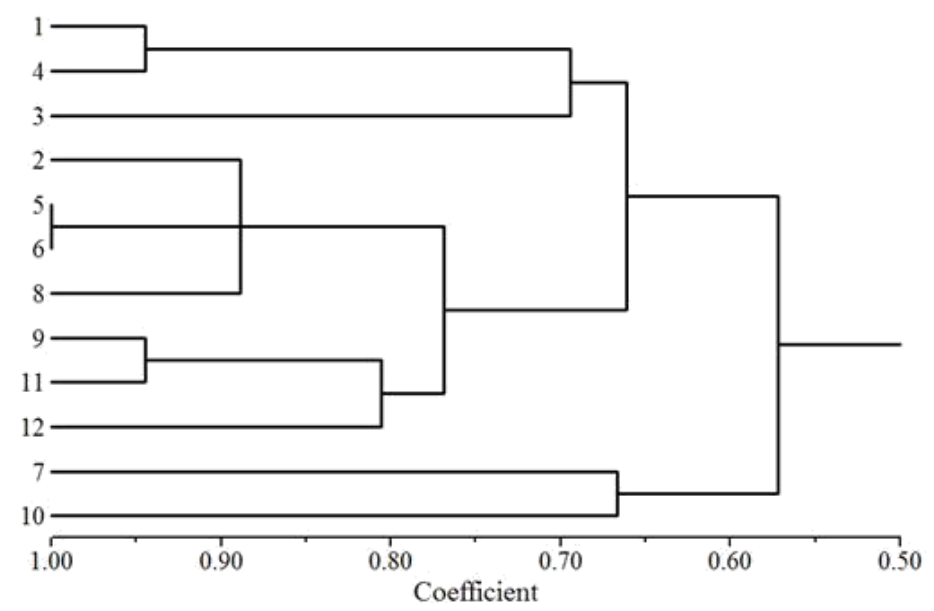

Figure 2- Cluster analysis of the adhesive gut bacterial communities of four species of Indian air-breathing fish based on the $16 \mathrm{~S}$ rDNA V3 region using denaturing gradient gel electrophoresis fingerprints.

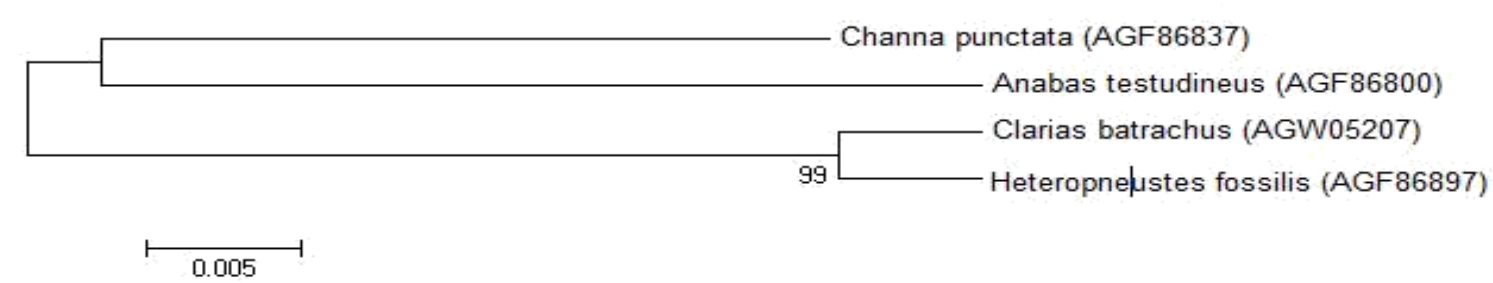

Figure 3- Neighbour-joining tree of the COI sequences in the four fish species and their closest relative sequences deposited in the NCBI database. Data represented two major cluster formed by C. punctatus-A. testudineus and $C$. batrachus-H fossilis.

Table 3- Pair-wise similarity coefficients (Cs) matrix for gut bacterial community.

\begin{tabular}{llllllllllll}
\hline & 1 & 2 & 3 & 4 & 5 & 6 & 7 & 8 & 9 & 10 & 11 \\
\hline 1 & 1.0 & & & & & & & & & & \\
2 & 0.72 & 1.0 & & & & & & & & & \\
3 & 0.72 & 0.67 & 1.0 & & & & & & & & \\
4 & 0.94 & 0.78 & 0.67 & 1.0 & & & & & & & \\
5 & 0.72 & 0.89 & 0.78 & 0.72 & 1.0 & & & & & & \\
6 & 0.72 & 0.89 & 0.78 & 0.72 & 1.0 & 1.0 & & & & & \\
7 & 0.44 & 0.61 & 0.39 & 0.50 & 0.61 & 0.61 & 1.0 & & & & \\
8 & 0.44 & 0.89 & 0.67 & 0.61 & 0.89 & 0.89 & 0.72 & 1.0 & & & \\
9 & 0.72 & 0.89 & 0.56 & 0.61 & 0.78 & 0.78 & 0.72 & 0.89 & 1.0 & & \\
10 & 0.44 & 0.50 & 0.39 & 0.56 & 0.61 & 0.61 & 0.67 & 0.61 & 0.61 & 1.0 & \\
11 & 0.56 & 0.83 & 0.50 & 0.61 & 0.72 & 0.72 & 0.67 & 0.83 & 0.94 & 0.56 & 1.0 \\
12 & 0.50 & 0.67 & 0.44 & 0.72 & 0.67 & 0.67 & 0.61 & 0.78 & 0.78 & 0.72 & 0.83 \\
\hline
\end{tabular}

Regarding the allochthonous gut microbiota, a Cs value of 0.94 between allochthonous microbiota of climbing perch (1; entire intestine) and murrel (4; entire intestine), while for allochthonous microbiota of walking catfish (7; entire intestine) and stinging catfish (10; entire intestine) a Cs value of only 0.67 was detected. The highest Cs value, high degree of similarity
(1.0) was detected between the autochthonous microbiota in PI and DI of murrel, in contrast to a Cs value of 0.67 for the autochthonous microbiota in PI and DI of climbing perch. The autochthonous microbiota in PI for climbing perch and murrel was 0.89 , while the Cs value in DI of climbing perch and murrel was 0.78 . A more closed cluster relationship between walking catfish 
and stinging catfish was observed (Cs value results of $\mathrm{PI}=0.83$ and for $\mathrm{DI}=0.78$ ).

Different intestinal contents and gut sections (PI and DI) of the four fish species had only one common band, band 8 (Table 4). Furthermore, PCR-DGGE analysis of murrel revealed one common band; band 11, while in samples from walking catfish and stinging catfish, band 9, 12 and 18 were common. Some bands were unique for one fish species. Climbing perch; band 1 - 3 (autochthonous in DI), band 14 (allochthonous), band 17 (allochthonous and autochthonous in PI) in walking catfish and in stinging catfish; band 5 and 6 (allochthonous and autochthonous in DI) and band 10 (autochthonous in PI and DI).

Table 4- Identification of 18 sequenced bands from 4 Indian air-breathing fish species.

\begin{tabular}{|c|c|c|c|c|c|c|c|c|c|c|c|c|c|c|c|}
\hline Phylum & No. & $\begin{array}{l}\text { Closest relative (obtained from } \\
\text { BLAST search) }\end{array}$ & $\begin{array}{l}\text { similarity } \\
(\%)\end{array}$ & 1 & 2 & 3 & 4 & 5 & 6 & 7 & 8 & 9 & 10 & 11 & 12 \\
\hline \multirow[t]{9}{*}{ Proteobacteria } & b1 & $\begin{array}{l}\text { Enterobacter cloacae } \\
\text { (HQ697282.1) }\end{array}$ & 99 & - & - & + & - & - & - & - & - & - & - & - & - \\
\hline & $\mathrm{b} 2$ & Edwardsiella tarda (HM003641.1) & 100 & - & - & + & - & - & - & - & - & - & - & - & - \\
\hline & b3 & Sphingobium sp. (HM005244.1) & 100 & - & - & + & - & - & - & - & - & - & - & - & - \\
\hline & $\mathrm{b} 4$ & $\begin{array}{l}\text { Uncultured Aeromonas sp. } \\
\text { (HQ658850.1) }\end{array}$ & 99 & + & - & + & + & - & - & - & - & - & - & - & - \\
\hline & b9 & $\begin{array}{l}\text { Stenotrophomonas sp. } \\
\text { (AB560630.1) }\end{array}$ & 100 & - & + & + & - & + & + & + & + & + & + & + & + \\
\hline & b11 & Acinetobacter sp. (GU290322.1) & 99 & + & - & + & + & + & + & + & - & - & + & - & + \\
\hline & b12 & $\begin{array}{l}\text { Acinetobacter lwoffii } \\
\text { (DQ341260.1) }\end{array}$ & 100 & - & - & - & - & - & - & + & + & + & + & + & + \\
\hline & b14 & $\begin{array}{l}\text { Stenotrophomonas sp. } \\
\text { (AB560630.1) }\end{array}$ & 99 & - & - & - & - & - & - & + & - & - & - & - & - \\
\hline & b17 & Pseudomonas sp. (HM468095.1) & 100 & - & - & - & - & - & - & + & + & - & - & - & - \\
\hline \multirow[t]{9}{*}{ Uncultured } & b5 & $\begin{array}{l}\text { Uncultured bacterium } \\
\text { (EU697160.1) }\end{array}$ & 100 & - & - & - & - & - & - & - & - & - & + & - & + \\
\hline & b6 & $\begin{array}{l}\text { Uncultured bacterium } \\
\text { (JF018065.1) }\end{array}$ & 100 & - & - & - & - & - & - & - & - & - & + & - & + \\
\hline & b7 & $\begin{array}{l}\text { Uncultured bacterium } \\
\text { (JF011316.1) }\end{array}$ & 100 & + & - & - & + & - & - & - & - & - & + & - & - \\
\hline & b8 & $\begin{array}{l}\text { Uncultured bacterium } \\
\text { (JF016709.1) }\end{array}$ & 95 & + & + & + & + & + & + & + & + & + & + & + & + \\
\hline & b10 & $\begin{array}{l}\text { Uncultured bacterium } \\
\text { (EU697160.1) }\end{array}$ & 100 & - & - & - & - & - & - & - & - & - & - & + & + \\
\hline & b13 & $\begin{array}{l}\text { Uncultured bacterium } \\
\text { (GQ360025.1) }\end{array}$ & 96 & - & - & + & - & + & + & - & - & - & + & - & - \\
\hline & b15 & $\begin{array}{l}\text { Uncultured bacterium } \\
\text { (JF016747.1) }\end{array}$ & 100 & - & - & - & - & - & - & + & - & - & + & - & - \\
\hline & b16 & $\begin{array}{l}\text { Uncultured bacterium } \\
\text { (JF018065.1) }\end{array}$ & 100 & - & - & - & - & - & - & + & - & - & + & - & - \\
\hline & b18 & $\begin{array}{l}\text { Uncultured bacterium } \\
\text { (EU697160.1) }\end{array}$ & 99 & - & - & - & - & - & - & + & + & + & + & + & + \\
\hline
\end{tabular}

\section{Sequences from DNA bands in DGGE gel}

Eighteen bands were successfully sequenced and the sequences of approximately $200 \mathrm{bp}$ were compared using a classifier tool in RDP (Ribosomal Database Project) are revealed in Table 4 . The only bacterial species common in the GI tract of the four species of Indian air-breathing fish was identified as an uncultured bacterium (band no. 8) revealing 95\% similarity to accession no. JF016709, which showed relatively low sequence similarities with the reference strains examined. Table 4 also revealed that band 1, 2 and 3were most closely related to Enterobacter cloacae $($ similarity $=99 \%)$, Edwardsiella tarda (100\% similarity) and Sphingobium sp. (100\% similarity), respectively. Band no. 4 was identified to uncultured Aeromonas sp. $($ similarity $=99 \%$ ) and was detected in entire intestine (allochthonous microbiota) and DI (autochthonous microbiota) of climbing perch, and 
as allochthonous in the entire intestine of murrel. Band no. 14 showed $99 \%$ similarity to Stenotrophomonas sp. but was only detected in allochthonous microbiota of walking catfish. Meanwhile, band no. 17 and 12 were assigned to Pseudomonas sp. a111-5 (100\% similarity) and Acinetobacter lwoffii strain F78, respectively.

The presences of the uncultured bacterium clones were different between the fish species and they were dominant as 10 out of 18 bands were identified as uncultured bacterium clones (Table 4). The uncultured bacterium clones; band no. 5 and 10 (both displaying $100 \%$ similarity to uncultured DGGE bacterium), band no. 6 (uncultured bacterium clone ncd320g09c1) and the uncultured bacteria clone ncd $112 \mathrm{e} 08 \mathrm{c} 1$; band no. 7 were detected.

\section{Phylogenetic analysis}

All four sequences for each species were included in the phylogenetic analysis of COI genes. The NJ trees (Fig. 3) revealed identical phylogenetic relationship among the species. Two major clusters were obtained with the first cluster formed by the climbing perch (A. testudineus) and murrel (C. punctatus). The second cluster was formed by the species walking catfish (C. batrachus) and stinging catfish (H. fossilis).

\section{DISCUSSION}

The aquaculture is the fastest growing food sector in all over the world. The economy of different countries like China, India, Norway, Malaysia, Indonesia, Brazil, Canada and USA are highly dependent on aquaculture production. The production cost of cultured fish are high due to high cost of feed preparation. The GI tract bacteria play a critical role in fish nutrition and diseases prevention. The knowledge on composition of fish GI tract bacteria is thus very important to optimize the feed efficiency which will ultimately reduce the production cost in aquaculture sectors. In this present study, four Indian air-breathing fish species have been selected to analyze the bacterial diversity in their GI tract using the PCR-DGGE approach. Air-breathing fish are known to generally inhabit the freshwater swamps and other water bodies in the tropical regions and are able to survive for long time outside water due to the presence of their specially developed air-breathing organs ${ }^{35}$. Due to the presence of air-breathing organs, these fish species are suitable for culture in such water bodies where gill-breathing species fail to survive. The four air-breathing fish species used in the present study; climbing perch, murrel, walking catfish and stinging catfish differ in their external features and by having different types of air- breathing organs. These fishes are suitable for culture in any type of water bodies where the culture of carps is not possible. The air-breathing fishes are generally carnivorous in feeding habit. Some reports are available on the culture dependent bacterial communities in the GI tract of air-breathing fish ${ }^{2,24,25}$, and these investigations revealed that the cultivable GI microbiota of both murrel and stinging catfish contained phytase, cellulase, protease, lipase and amylase-producing bacteria in PI and DI and they were identified as Bacillus licheniformis and Bacillus $\mathrm{sp}^{12}$. However, as conventional culture technique has limitation, further information is needed using a culture-independent approach.

The intestinal microbiota derived of the four fish species investigated in the present study could be divided into four groups based on the cluster analysis results and the relationship between intestinal microbiota and fish genotype by sequencing the fish cytochrome oxidase subunit 1(COI) gene. According to Hubert et $\mathrm{all}^{36}$ sequencing the fish cytochrome oxidase subunit 1 (COI) gene is an efficient DNA "barcoding" technique for identifying freshwater fish species and creating a phylogenetic tree. In the present study, the phylogenetic relationship reflected a similar dendogram tree of the intestinal microbiota, suggesting that fish genotype and intestinal bacteria showed co-evolution relationship. This result was similar to the results of Zoetendal et al. ${ }^{37}$, Kovacs et al. ${ }^{38}$ and Spor et al. ${ }^{39}$ revealing that genotype had a significant effect on gut microbiota in humans and mice. DGGE profiles of fecal bacterial 16S rDNA amplicons from adult humans with varying degrees of monozygotic twins were compared by determining the similarity indices of the profiles of unrelated individuals. The similarity between fecal DGGE profiles of monozygotic twins were significantly higher than those for unrelated individuals (ts $=2.73, \mathrm{p} 1$-tail $=0.0063, \mathrm{df}=21)$. In addition, a positive relationship ( $\mathrm{F} 1,30=8.63, \mathrm{p}=$ 0.0063 ) between the similarity indices and the genetic relatedness of the hosts was observed ${ }^{37}$. The autochthonous DI microbiota of walking catfish was not strict cluster together with stinging catfish. This may be attributed to the 
environmental factors interact to control the acquisition and to maintain gut microbiota. For example it is well established that dietary manipulations modulate the microbiota composition 27,34,40,41. As several DGGE bands were retrieved in the present study that have either rarely or never been reported previously as a part of the gut microbial community of the four Indian freshwater fish investigated, some general information is therefore presented here.

Enterobacter are Gram-negative, non-spore forming, facultative rod-shaped bacteria which can utilize lactose in presence of bile salt and detergent ${ }^{42}$. Trust and Sparrow ${ }^{26}$ reported Enterobacter sp. in the GI tract of freshwater salmon. In the present study, one DGGE band, no. 1 displayed high similarity $(99 \%)$ to E. cloaceae strain P 42 described by Moerschbacher and El Gueddari (unpublished data, National Center for Biotechnology Information (NCBI) http://www.ncbi.nlm.nih.gov/). As E. cloacae cause high mortality in flathead mullet (Mugil cephalus) ${ }^{43}$, further studies are warranted evaluating whether E. cloaceae detected in the present study has any negative effect on health of Indian air- breathing fish species. Similarly, the genus Edwardsiella is a rod-shaped, Gramnegative, fermentative bacteria belongs to the family Enterobacteriaceae. E. tarda is an important member of this family and is distributed in fish where it can cause septicemia ${ }^{44}$. Band no. 2 showed $100 \%$ similarity to $E$. tarda strain GD080715-1 reported by Chen et al. (unpublished data, NCBI). Whereas, Sphingobium is Gram negative, aerobic, non-sporulating, rod shaped, non-motile bacteria which are widely distributed in contaminated soil, mainly clinical wastes ${ }^{45}$. From the biotechnological point of view, genus Sphingobium is very important as it is involved in different biodegradation pathway, such as degradation of methane and phenol by Sphingobium yanoikuyae strain FM-2 and Sphingobium fuliginis, respectively ${ }^{46,47}$.To our knowledge; Sphingobium sp. has not been reported in Indian freshwater fish. Sphingobacterium spp. Commonly isolated from the GI tract of rainbow trout (Oncorhynchus mykiss) ${ }^{48}$. However, in the present study, DGGE band no. 3 revealed 100\% similarity to Sphingobium sp. CO132 reported in a study evaluating anti- protease and immunomodulatory activities of bacteria associated with Caribbean sponges ${ }^{49}$.
In a study on microbial community analysis of three municipal wastewater treatments plants in winter and spring by culture-dependent and culture-independent methods, Cui et al. ${ }^{50}$ reported information on uncultured Aeromonas sp. clone hrb-449, accession no. HQ658850. Band no. 4 in the present study revealed high similarity to this accession number. Stenotrophomonas are Gramnegative, aerobic, motile, non-fermentative bacteria which were previously grouped in the genus Xanthomonas ${ }^{51}$. S. maltophiliais the most important member of this group ${ }^{52}$ and is considered to be a potent human pathogen ${ }^{53,54}$. Furushita et al. ${ }^{55}$ isolated and characterized $S$. maltophilia from the cultured marine fish, Seriola quinqueradiata. DGGE band no. 9 and 14 revealed high similarities to Stenotrophomonas sp. TeRB010 previously reported by

Someya et al. ${ }^{56}$ in a study have also investigated the diversity of culturable chitinolytic bacteria from rhizospheres of agronomic plants in Japan. Whether, Stenotrophomonas detected in the present study can contribute to nutrition of the fish species investigated in the present study has not been elucidated and merits further investigations.

Acinetobacter are Gram-negative, oxidasenegative, catalase-positive and rod-shaped bacteria which have been isolated from the digestive tract of finfish ${ }^{57,58}$. However, to our knowledge the genus has not previously been reported in India freshwater fish. In the present study, DGGE band no. 12 , revealed $100 \%$ similarity to Acinetobacter lwoffii strain F78 reported by Hanuszkiewicz et al. (unpublished data, NCBI) and band no. 11 displaying $99 \%$ similarity to Acinetobacter sp. 200915 described by Duan et al. (unpublished data, NCBI). Of the 18 bands reported in the present study, 11 bands revealed high similarities to uncultured bacterium isolates or uncultured clones illustrating that the gut microbiota of Indian freshwater fish is highly diverse.

\section{CONCLUSION}

The present investigation demonstrated the composition of dominant intestinal bacterial flora (both autochthonous and allochthonous) of four Indian air-breathing fish species namely $A$. testudineus, C. punctatus, C. batrachus and $H$. fossilis. To the authors' knowledge, it is the first report of both autochthonous and allochthonous bacterial flora in the GI tract of these fish species. 
Previous studies have reported the bacterial composition in these air-breathing fish using culture dependent techniques, which is not sufficient to draw the exact picture of the microbial communities. Most of the bacterial species in the GI tract are non-culturable and thus culture independent techniques such as DEGE, TGGE and Next Generation Sequencing (NGS) are important to explore the microbial ecosystem of gut. The difference in bacterial community in GI tract of these four fish species is due to different feeding habit. Despite their differences in the intestinal microbiota, our data also indicated that factors related to the host genotype have an important effect on the bacterial community in the GI tract. The present study clearly demonstrated that the GI tract of these fish species is dominated by non-cultural bacterial species. This discrepancy highlights that further studies are needed to evaluate the gut microbiota of air-breathing fish. In addition, determination of the physiological role of the intestinal microbiota merits further investigations.

\section{REFERENCES}

1-Nayak SK. Role of gastrointestinal microbiota in fish. Aquacult Res. 2010; 41: 1553-1573.

2-Banerjee G, Ray AK, Askarian F, Ringø E. Characterization and identification of enzymeproducing autochthonous bacteria from the gastrointestinal tract of two Indian air-breathing fish. Benef Microb. 2013; 4: 277-284.

3-Sommer F, Bäckhed F. The gut microbiota-masters of host development and physiology. Nat Rev Microb. 2013; 11: 227-238.

4-Cahill MM. Bacterial flora of fishes. A review. Micro Ecol. 1990; 19: 21-41.

5-Saha S, Roy RN, Sen SK, Ray AK. Characterization of cellulase-producing bacteria from the digestive tract of tilapia, Oreochromis mossambica (Peters) and grass carp, Ctenopharyngodon idella (Valenciennes). Aquacult Res. 2006; 37: 380-388.

6-Ring $\varnothing \mathrm{E}$, Birkbeck TH. Intestinal microbiota of fish larvae and fry. Aquacult Res. 1999; 26: 773-789.

7-Saha AK, Ray AK. Cellulase activity in rohu fingerlings. Aquacult Int. 1998; 16: 281-291.

8-Bairagi A, Sarkar Ghosh K, Sen S., Ray AK. Enzyme producing bacterial flora isolated from fish digestive tracts. Aquacult Int. 2002; 10: 109-121.

9-Mondal S, Roy T, Sen SK, Ray AK. Distribution of enzyme-producing bacteria in the digestive tracts of some freshwater fish. Acta Ichthyologica et Piscatoria. 2008; 38: 1-8.
10- Mondal S, Roy T, Ray AK. Characterization and identification of enzyme-producing bacteria isolated from the digestive tract of bata, Labeo bata. J World Aquacult Soc. 2010; 41: 369-377.

11- Ray AK, Roy T, Mondal S, Ring $\varnothing$ E. Identification of gut-associated amylase, cellulase and protease-producing bacteria in three species of Indian major carps. Aquacult Res. 2010; 41: 1462 1469.

12- Ray AK, Ghosh K, Ring $\varnothing$ E. Enzymeproducing bacteria isolated from fish gut: a review. Aquacult Nutr. 2012; 18: 465-492.

13- Gomez GD, Balcázar JL. A review on the interactions between gut microbiota and innate immunity of fish. FEMS Immunol Med Microbiol. 2008; 52: 145-154.

14- Merrifield DL, Dimitroglou A, Foey A, Davies SJ, Baker RR, Bøgwald J, et al. The current status and future focus of probiotic and prebiotic applications for salmonids. Aquaculture. 2010; 302: $1-18$.

15- $\quad$ Ringø E, Strøm E, Tabachek JA. 1995. Intestinal micro flora of salmonids: a review. Aquacult Res. 26:773-789.

16- Asfie M, Yoshijima T, Sugita H. Characterization of the goldfish fecal microbiota by the fluorescent in situ hybridization method. Fish Sci. 2003; 69: 21-26.

17- Kim D-H, Brunt J, Austin B. Microbial diversity of intestinal contents and mucus in rainbow trout (Oncorhynchus mykiss). J Appl Microbiol. 2007; 102: 1654-1664.

18- Liu W, Ren P, He S, Xu L, Yang Y, Gu Z, et al. Comparison of adhesive gut bacteria, immunity, and disease resistance in juvenile hybrid tilapia fed different Lactobacillus strains. Fish Shellfish Immunol. 2013; 35: 54-62.

19- $\quad$ Ren P, Xu L, Yang Y, He S, Liu W, Ringø E, et al. Lactobacillus plantarum sub sp. plantarum JCM 1149 vs. Aeromonas hydrophila NJ-1 in the anterior intestine and posterior intestine of hybrid tilapia Oreochromis niloticus $9 \times$ Oreochromis aureus ${ }^{\lambda}$ : an ex vivo study. Fish Shellfish Immunol. 2013; 35: 146-153.

20- Zhou Z, Yao B, Romero J, Waines P, Ring $\varnothing$ E, Emery M, et al. (2014) In: Merrifield DL, Ring $\varnothing$ E. editors. Methodological approaches used to assess fish gastrointestinal communities. Aquaculture Nutrition, Probiotics and Prebiotics. Oxford, UK: Wiley-Blackwell Publishing, in press.

21- Liu Y, Zhou Z, Yao B, Shi P, He S, Hølvold $\mathrm{LB}$, et al. Effect of intraperitoneal injection of immune stimulatory substances on allochthonous gut microbiota of Atlantic salmon (Salmo salar L.) determined using denaturing gradient gel electrophoresis. Aquacult Res. 2008; 39: 635-646.

22- Mouchet MA, Bouvier C, Bouvier T, Troussellier M, Escalas A, Mouillot D. Genetic 
He, S et al.

difference but functional similarity among fish gut bacterial communities through molecular and biochemical fingerprints. FEMS Microbiol Ecol. 2012; 79: 568-580.

23- Ercolini D. PCR-DGGE fingerprinting: novel strategies for detection of microbes in food. $J$ Microbiol Meth. 2004; 56: 297-314.

24- Banerjee G, Ray AK. Characterization and identification of protease and amylase-producing bacteria isolated from the gastrointestinal tract of climbing perch, Anabas testudineus (Bloch). Decan Curr Sci. 2013; 9: 150-159.

25- Dan SK, Ray AK. Characterization and identification of phytase-producing bacteria isolated from the gastrointestinal tract of four freshwater teleosts. Ann Microbiol. 2014; 64: 297-306.

26- Trust TJ, Sparrow RAH. The bacterial flora in the alimentary tract of freshwater salmonid fish. Can J Microbiol. 1974; 20: 1219-1228.

27- $\quad$ He S, Zhou Z, Liu Y, Shi P, Yao B, Ringø E, et al. Effects dietary yeast culture Saccharomyces cerevisiae fermentation product (DVAQUA ${ }^{\circledR}$ ) on growth performance, intestinal autochthonous bacterial community and non-specific immunity of hybrid tilapia (Oreochromis niloticus $\bigcirc \times$ O. aureus $\bigcirc$ ) cultured in cages. Aquaculture. 2009; 294: 99-107.

28- Hovda MB, Lunestad BT, Fontanillas R, Rosnes JT. Molecular characterisation of the intestinal microbiota of farmed Atlantic salmon (Salmo salar L.). Aquaculture. 2007; 272: 581-588.

29- Zhou Z, Liu Y, He S, Shi P, Yao B, Ring $\varnothing$ E. Molecular characterisation of the autochthonous microbiota in the gastrointestinal tract of adult yellow grouper (Epinephelus awoara) cultured in cages. Aquaculture. 2009; 286: 184-189.

30- Zhou Z, Shi P, He S, Liu Y, Huang G, Yao B, et al. Identification of adherent microbiota in the stomach and intestine of emperor red snapper (Lutjanus sebae Cuvier) using 16S rDNA-DGGE. Aquacult Res. 2009; 40: 213-1218.

31- Spanggaard B, Huber L, Nielsen J, Nielsen T, Appel KF, Gram L. The microflora of rainbow trout intestine: a comparison of traditional and molecular identification. Aquaculture. 2000; 182: 1-15.

32- Ring $\varnothing$ E, Sperstad S, Myklebust R, Mayhew TM, Mjelde A, Melle W, et al. The effect of dietary krill supplementation on epithelium-associated bacteria in the hindgut of Atlantic salmon (Salmo salar L.): a microbial and electron microscopical study. Aquacult Res. 20006; 37: 1644-1653.

33- $\quad \mathrm{Yu} \mathrm{Z}$, Morrison M. Improved extraction of PCR-quality community DNA from digesta and fecal samples. Biotech. 2004; 36: 808-812.

34- Zhou Z, He S, Liu YC, Shi P, Huang GX, Yao B. The effects of dietary yeast culture or shortchain fructo-oligosaccharides on the intestinal autochthonous bacterial communities in juvenile hybrid tilapia, Oreochromis niloticus $\bigcirc \times$ O. aureus $\widehat{\emptyset}$. $J$ World Aquacult Soc. 2009; 40: 450-459.

35- Bruton M. The survival of habitat desiccation by air breathing clariid catfishes. Environ Biol Fish. 1979; 4: 273-280.

36- Hubert N, Hanner R, Holm E, Mandrak NE, Taylor E, Burridge M, Watkinson D, Dumont $\mathrm{P}$, Curry A, Bentzen $\mathrm{P}$, et al. Identifying Canadian freshwater fishes through DNA. barcodes. PLoS One. 2008; 3: e2490.

37- Zoetendal EG, Akkermans ADL, Akkermansvan Vliet WM, de Visser JAGM, de Vos WM. The host genotype affects the bacterial community in the human gastrointestinal tract. Microb Ecol Health Dis. 2001; 13: 129-134.

38- Kovacs A, Ben-Jacob N, Tayem H, Halperin E, Iraqi F, Gophna U. Genotype is a stronger determinant than sex of the mouse gut microbiota. Microb Ecol. 2011; 61: 423-428.

39- Spor A, Koren O, Ley R. Unravelling the effects of the environment and host genotype on the gut microbiome. Nat Rev Micro. 2011; 9: 279-290.

40- Ring $\varnothing$ E, Olsen RE. The effect of diet on aerobic bacterial flora associated with intestine of Arctic charr (Salvelinus alpinus L.). J Appl Microbiol. 1999; 86: 22-28.

41- $\quad$ Ring $\varnothing$ E, Zhou Z, Olsen RE, Song SK. Use of chitin and krill in aquaculture - effect on gut microbiota and the immune system: A review. Aquacult Nutr. 2012; 18: 117-131.

42- Cabral JPS. Water Microbiology. Bacterial pathogens and water. Int $J$ Environ Res Public Health. 2010; 7: 3657-3703.

43- Sekar VT, Santiago TC, Vijayan KK, Alavandi SV, Raj VS, Rajan JJ, et al. Involvement of Enterobacter cloacae in the mortality of the fish, Mugil cephalus. Lett Appl Microbiol. 2008; 46: 667-72.

44- Janda J, Abbott S. The Genus Edwardsiella. In: The Enterobacteria, Second Edition. ASM Press, Washington, DC. 2006. p. 301-320.

45- Takeuchi M, Hamana K, Hiraishi A. Proposal of the genus Sphingomonassensustrictoand three new genera, Sphingobium, Novosphingobium and Sphingopyxis, on the basis of phylogenetic and chemotaxonomic analyses. Int $J$ Syst Evol Microbiol. 2001; 151: 1405-1417.

46- Inoue D, Hara S, Kashihara M, Murai Y, Danzl E, Sei K, et al. Degradation of bis (4Hydroxyphenyl) methane (bisphenol F) by Sphingobium yanoikuyae strain FM-2 Isolated from river water. Appl Environ Microbiol. 2008; 74: 352358.

47- Ogata Y, Goda S, Toyama T, Sei K, Ike M. The 4-tert-butylphenol-utilizing bacterium Sphingobiumfuliginis OMI can degrade bisphenols via phenolic ring hydroxylation 
and meta-cleavage pathway. Environ Sci Technol. 2013; 47: 1017-1023.

48- Heikkinen J, Vielma J, Kemiläinen O, Tiirola M, Eskelinen P, Kiuru T, et al. Effects of soybean meal based diet on growth performance, gut histopathology and intestinal microbiota of juvenile rainbow trout (Oncorhynchus mykiss). Aquaculture. 2006; 261: 259-268.

49- Tabares P, Pimental-Elardo SM, Schirmeister $\mathrm{T}$, Hüning $\mathrm{T}$, Hentschel U. Anti-protease and immunomodulatory activities of bacteria associated with Caribbean sponges. Mar Biotechnol. 2011; 13: 883-892.

50- Cui D, Li A, Zhang S, Pang C, Yang J, Gup J, et al. Microbial community analysis of three municipal wastewater treatments plants in winter and spring using culture-dependent and cultureindependent methods. World J Microbiol Biotechnol. 2012; 28: 2341-2353.

51- Palleroni N, Bradbury J. Stenotrophomonas, a new bacterial genus for Xanthomonas maltophilia (Hugh 1980) Swings et al. 1983". Int J Syst Bacteriol. 1993; 43: 606-609.

52- Schoch PE, Cunha BA. Pseudomonas maltophilia. Infect Cont. 1987; 8: 169-172.

53- Waters V, Gómez M, Soong G, Amin S, Ernst R, Prince A. Immunostimulatory properties of the emerging pathogen Stenotrophomonas maltophilia. Infect Immunol. 2007; 75: 1698-703.

54- Kwa AL, Low JG, Lim TP, Leow PC, Kurup A, Tam VH. Independent predictors for mortality in patients with positive Stenotrophomonas maltophilia cultures. Ann Acad Med Singapore. 2008; 37: 82630.

55- Furushita M, Okamoto A, Maeda T, Ohta M, Shiba T. Isolation of multidrugresistant Stenotrophomonas maltophilia from cultured yellowtail (Seriola quinqueradiata) from a marine fish farm. Appl Environ Microbiol. 2005; 71: 5598-5600.

56- $\quad$ Someya N, Ikeda S, Morohoshi T, Tsujimoto MN, Yoshida T, Sawada H, et al. Diversity of culturable chitinolytic bacteria from rhizospheres of agronomic plants in Japan. Micro Environ. 2011; 26: 7-14.

57- Holben WE, Williams P, Saarinen M, Sarkilahti LK, Apajalahti JHA. Phylogenetic analysis of intestinal microflora indicates a novel Mycoplasma phylotype in farmed and wild salmon. Microb Ecol. 2002; 144: 175-185.

58- Gonzalez CJ, Santos JA, Garcia-Lopez ML, Gonzalez N, Otero A. Mesophilic aeromonads in wild and aquacultured freshwater fish. J Food Protect. 2001; 64: 687-691.

59- Jhingran VG. Fish and fisheries of India. 3rd ed. New Delhi: Hindustan Publishing Corporation; 1997. p. 335-337. 